\title{
Evaluation of silibinin as an efflux pump inhibitor in Bacillus subtilis
}

\author{
Fatma Ece Altinisik Kaya ${ }^{\circledR 1}$, Basak Atas ${ }^{\circledR 1}$, Fatma Gizem Avci ${ }^{\text {2, }}$,
}

\begin{abstract}
${ }^{1}$ Marmara University, Faculty of Engineering, Department of Bioengineering, Istanbul, Turkey
${ }^{2}$ Uskudar University, Faculty of Engineering and Natural Sciences, Department of Bioengineering, Istanbul, Turkey
\end{abstract}

\begin{abstract}
Antibiotic resistance has become a global health problem for humankind. Improper use of antibiotics resulted in the increasing evolved bacterial resistance to them. There are different types of bacterial resistance mechanisms including efflux pumps. To overcome the efflux pump activity on the drugs, combinatorial therapy of the existing antimicrobials with natural products is a promising insight to prevent increasing multidrug resistance. In this study, the inhibitory action of a plant-derived molecule silibinin on efflux pumps of Bacillus subtilis was investigated. The cellular effect of silibinin was investigated using minimum inhibitory concentration and growth studies. In addition, the efflux pump action of silibinin was monitored by ethidium bromide accumulation assay on the organism. According to results, silibinin has a MIC value between $100-200 \mu \mathrm{gmL}^{-1}$ on microplate assay and $100 \mu \mathrm{gmL}^{-}$ ${ }^{1}$ of silibinin inhibited the cell growth. Ethidium bromide accumulation assays were performed at a safe silibinin range $\left(25\right.$ and $\left.50 \mu \mathrm{gmL}^{-1}\right)$ for eliminating the cell death, and ethidium bromide accumulation was increased with the increasing silibinin concentration. Ethidium bromide accumulation and growth results proved that silibinin has significant efflux pump inhibitor activity on Bacillus subtilis cells and silibinin is a promising inhibitor candidate to eliminate bacterial resistance mechanism.
\end{abstract}

\section{ARTICLE HISTORY}

Received: Jan. 19, 2021

Revised: Apr. 25, 2021

Accepted: May 01, 2021

\section{KEYWORDS}

Silibinin,

Efflux pump inhibitor,

Bacillus subtilis,

Multidrug resistance.

\section{INTRODUCTION}

Increased pressure imposed by improper and reckless use of antimicrobial agents has triggered the pace in development and transmission of bacterial resistance (Schwarz and Chaslus-Dancla, 2001). The non-susceptibility developed by bacteria to different classes of antimicrobials has led to the emergence of multidrug resistance (MDR) which is one of the most important global health threats (Magiorakos et al., 2012). The basic types of resistance mechanisms are known as enzymatic inactivation of the antimicrobials, modification of the target sites, reducing the intracellular accumulation of antimicrobials by arranging influx/efflux mechanisms (Van Duijkeren et al., 2018). Among these, efflux systems are considered as the major mechanisms

\footnotetext{
*CONTACT: Fatma Gizem Avci $\bigotimes$ gizemavci@gmail.com Uskudar University, Faculty of Engineering and Natural Sciences, Department of Bioengineering, Istanbul, Turkey
} 
that lead to MDR. These systems which are commonly comprised of transmembrane proteins enable the organisms to keep the concentrations of a wide range of different compounds at nontoxic levels by preventing their intracellular accumulation.

Efflux pumps are classified into six families based on their structure. These are (i) major facilitator superfamily (MFS), (ii) multidrug and toxic compound extrusion (MATE) family, (iii) small multidrug resistance (SMR) family, (iv) resistance-nodulation-cell division (RND) family, (v) ATP-binding cassette (ABC) superfamily, and (vi) proteobacterial antimicrobial compound efflux (PACE) superfamily. The latest one has been recently identified therefore its transport mechanism has not been clarified yet. Among the rest, only the ABC-type utilizes ATP while the other four families use proton motive force (PMF) for efflux (Du et al., 2015; Lamut et al., 2019).

The loss in available drug efficacies and the decrease in new antimicrobial discovery rates have increased the search on alternative strategies including combinatorial therapies. Combinatorial therapies of existing antimicrobials with natural products emerge as attractive approaches in the fight with increasing MDR. To this end, utilization of efflux pump inhibitors (EPIs) to interfere with efflux is one of the major strategies. Plants are immense sources of natural compounds, some of which are potential EPIs, so they are of utmost importance in the discovery of new antimicrobial agents. Isolation and identification of new EPIs will bring antimicrobials with lost efficacies back into the clinic. To date, many plant-based EPIs have been identified as reserpine (Gibbons et al., 2003; Neyfakh et al., 1991), piperine (Kumar et al., 2008), roemerine (Avci et al., 2019), baicalein (Chan et al., 2011), 5'-methoxy-hydnocarpin (Stermitz et al., 2000), and catechin gallates (Gibbons et al., 2004).

Silibinin (or silybin) is the major component of silymarin extract from the seeds of Silybum marianum (or milk thistle, Asteraceae) and a member of flavonolignans. (Dobiasová et al., 2020). It receives wide attention due to its anticancer, antioxidant, antibacterial, antifungal, antiinflammatory, cardioprotective, neuroprotective, and hepatoprotective activities (de Oliveira et al., 2015; Shen et al., 2018; Wlcek et al., 2013). More recently, silibinin has also been associated with an EPI property as it inhibited the efflux of norfloxacin through the NorA efflux pump protein in Staphylococcus aureus (Mahmood et al., 2016).

In the present study, the ability of silibinin to inhibit the efflux pumps of Bacillus subtilis was evaluated using minimum inhibitory concentration determination, growth studies, and ethidium bromide accumulation assay. Berberine was used in growth studies since it is the substrate of many efflux pumps and its activity is weakened due to the activity of efflux pumps (Avci et al., 2019). The clinical importance of B. subtilis is limited, it constitutes one of the model organisms for low $\mathrm{G}+\mathrm{C}$ Gram-positives with a significant genomic abundance of multidrug transporters. $B$. subtilis is also the first microorganism in which the bacterial MDR phenomenon was discovered. Furthermore, it possesses a mechanism analogous to the mammalian multidrug transporter, P-glycoprotein (Lorca et al., 2007; Neyfakh et al., 1991)

\section{MATERIAL and METHODS}

\subsection{Bacterial Strains and Chemicals}

The efflux pump inhibitor (EPI) property of silibinin was tested in wild-type Bacillus subtilis 168 (DSM 402). Silibinin (CAS No. 22888-70-6) and berberine chloride hydrate (CAS No. 141433-60-5) were obtained from Sigma-Aldrich. Silibinin and berberine solutions were prepared in dimethyl sulfoxide (DMSO) (Duchefa, Netherlands).

\subsection{Minimum Inhibitory Concentration (MIC) Determination for Silibinin}

Minimum inhibitory concentration (MIC) of silibinin was determined via broth micro-dilution assay (Amsterdam, 1997). Two-fold serial dilutions of silibinin from $200 \mu \mathrm{gmL}^{-1}$ to 0.097 
$\mu \mathrm{gmL}^{-1}$ were prepared with Nutrient Broth (NB, Merck, Germany) in sterile 96-well U-bottom plates and a single line of the test plate was prepared with serial dilutions of the solvent DMSO as control. Each well was inoculated with $10^{5} \mathrm{CFUmL}^{-1}$ cells. After a 24-hour incubation at $37^{\circ} \mathrm{C}$, 2,3,5-triphenyltetrazolium chloride (TTC) (Sigma, Germany) dye reduction test was utilized to determine the wells with no visible cell growth. TTC solution at a final concentration of $0.5 \%(\mathrm{w} / \mathrm{v})$ was added into each well. Plates were incubated at $37^{\circ} \mathrm{C}$ for 1 hour. MIC was determined based on the color change in wells. Viable cells were recognized with the development of red color in the wells.

\subsection{Growth Conditions}

B. subtilis 168 cells were grown in NB medium at $37^{\circ} \mathrm{C}$ and $180 \mathrm{rpm}$ and treated with silibinin, berberine, or silibinin-berberine combination as $\mathrm{OD}_{600}$ reached $0.45-0.55$. Control cells were only treated with equal volume of DMSO. The growth of the cells was monitorized spectrophotometrically by measuring $\mathrm{OD}_{600}$ values in 1-hour intervals.

\subsection{Ethidium Bromide Accumulation Assay}

A modified version of the previously reported method was used to perform ethidium bromide (EtBr) accumulation assay (Jin et al., 2011; Steinfels et al., 2004).

After overnight growth, B. subtilis 168 cells were inoculated into a tube containing $5 \mathrm{~mL}$ fresh $\mathrm{NB}$ and grown at $37^{\circ} \mathrm{C}$ and $180 \mathrm{rpm}$ until $\mathrm{OD}_{600}$ reached 0.5 . Cells were then centrifuged for $4 \mathrm{~min}$ at 2,000 $\mathrm{g}$ and $4^{\circ} \mathrm{C}$. Cell pellets were suspended in $2 \mathrm{~mL}$ of $0.35 \mathrm{M}$ sodium chloride $(\mathrm{NaCl}) .180 \mu \mathrm{L}$ of the cell suspension was mixed with $50 \mathrm{mM} \mathrm{KP}, 5 \mathrm{mM}$ magnesium sulfate ( $\mathrm{MgSO}_{4}$ ), and $25 \mathrm{mM}$ glucose. $10 \mu \mathrm{M}$ of EtBr (Invitrogen, California, USA) was added to the mixture immediately after the addition of glucose. Silibinin treatment $\left(25\right.$ and $\left.50 \mu \mathrm{gmL}^{-1}\right)$ was made prior to the addition of glucose. Control samples were supplied with an equal volume of DMSO. Fluorescence intensities were monitored for 20 min via Synergy HTX Multi-Mode Reader Reader (BioTek Instruments, Inc., Winooski, VT, USA) with excitation at $540 \mathrm{~nm}$ and emission at $590 \mathrm{~nm}$ (Serçinoğlu et al., 2020).

\section{RESULTS and DISCUSSION}

Antibiotic resistance development against available antimicrobials has reached alarming rates which causes a bottleneck during the fight against bacterial infections. Since the novel antibiotics with different targets are limited, the discovery of new antimicrobial classes has a high priority. Plant-derived molecules may be considered as potential alternatives to existing drugs with their various biological activities and multi-target properties. In spite of that, the limited information about their mechanisms restricts their use.

Silibinin has been reported to display diverse biological activities including antimicrobial, antioxidant, anticancer, anti-inflammatory, free radical scavenging, and membrane stabilizing properties under in vitro and in vivo conditions (Cai et al., 2017; de Oliveira et al., 2015). It has also been reported that silibinin inhibits P-glycoprotein-mediated cellular efflux (Zhou et al., 2004) and is involved in bacterial resistance through drug efflux (Wang et al., 2018). In the light of these recent findings, EPI property of silibinin was evaluated on the Gram-positive model organism B. subtilis 168 . Following the analysis of cellular growth in the presence of silibinin alone and in a combinatorial treatment, the contribution of silibinin to intracellular EtBr accumulation was monitored.

\subsection{Berberine and Silibinin Combinatorial Treatments}

Broth micro-dilution assay was carried out to find that the MIC of silibinin lied between 100$200 \mu \mathrm{gmL}^{-1}$ (Figure 1). In order to study the EPI property of silibinin, a working concentration 
that is well below its MIC value was selected. Thus, microbial growth studies were carried out in the presence of increasing silibinin concentrations from 25 to $100 \mu \mathrm{gmL}^{-1}$ (Figure 2).

Figure 1. Minimum inhibitory concentration (MIC) determination for silibinin.

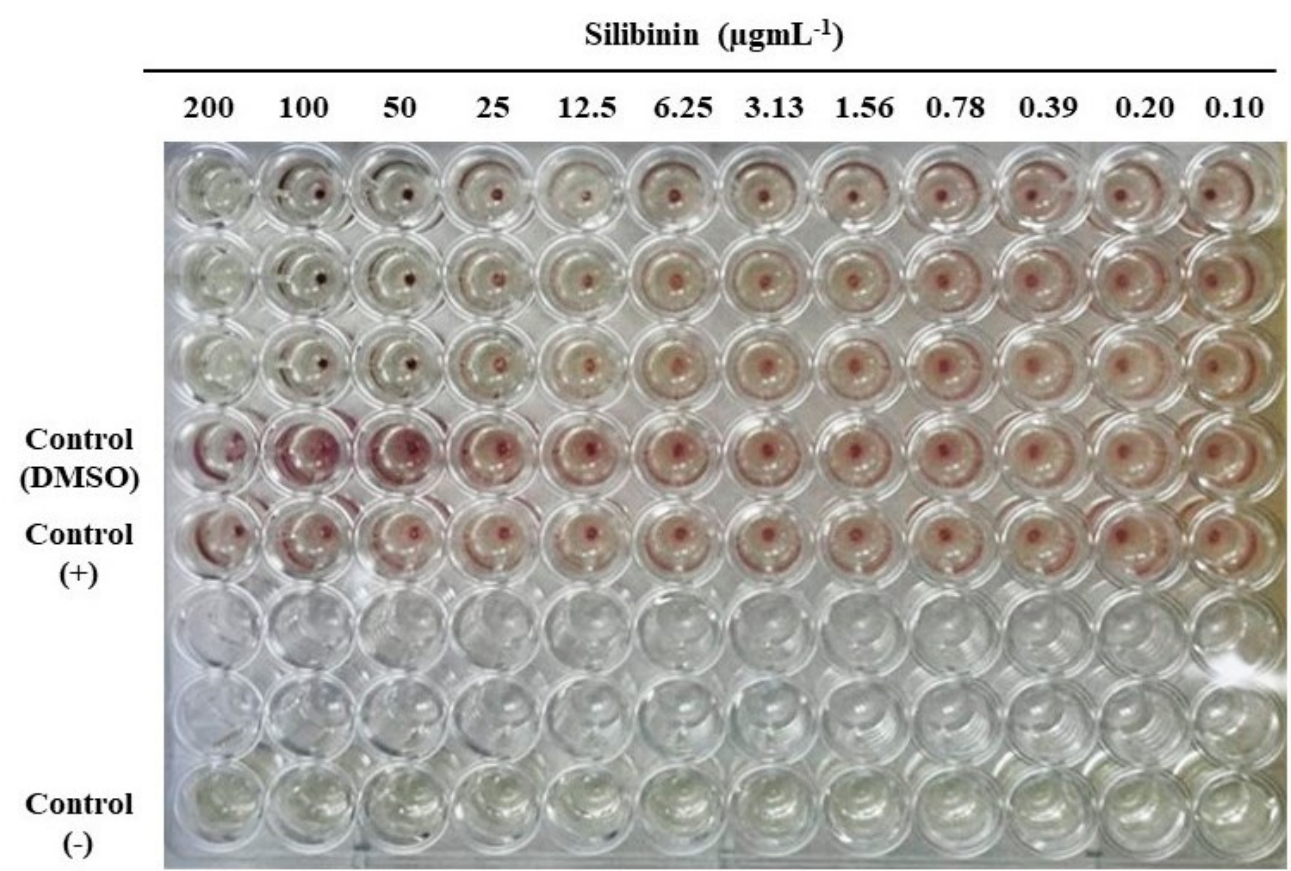

Treatment of the cells with $25 \mu \mathrm{gmL}^{-1}$ silibinin barely altered the growth profile of $B$. subtilis 168 cells whereas treatment with $50 \mu_{\mathrm{gmL}}{ }^{-1}$ silibinin led to a slight retardation in growth. When silibinin concentration was raised to $75 \mu \mathrm{gmL}^{-1}$, growth was severely affected. With $100 \mu \mathrm{gmL}^{-}$ ${ }^{1}$ there was no growth at all. Growth curves obtained with increasing silibinin concentrations have shown that $25 \mu \mathrm{gmL}^{-1}$ silibinin is suitable for testing its EPI feature since it did not alter growth.

Figure 2. Microbial growth under increasing silibinin concentrations.

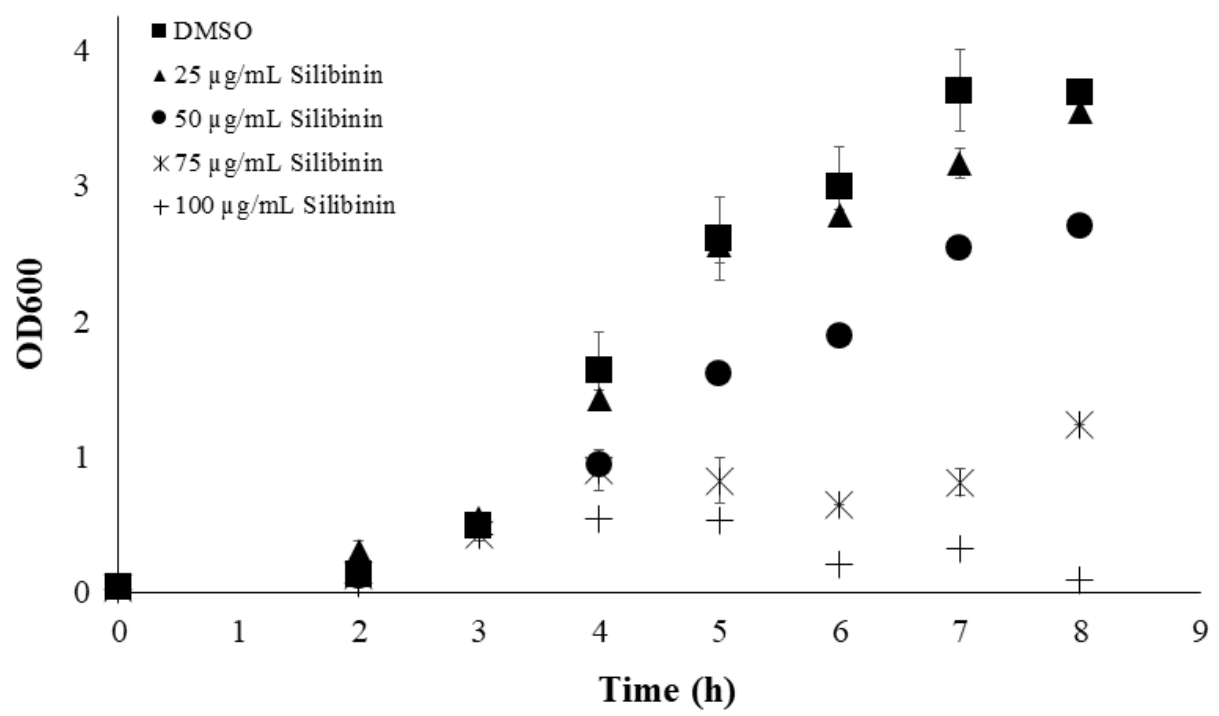


The antimicrobial berberine is widely known to be a substrate of a number of drug efflux pumps therefore its combination with different natural pump inhibitors may offer a way to enhance its efficacy (Avci et al., 2019; Stermitz et al., 2000). In order to evaluate the EPI property of silibinin, its combination with berberine has been tested on B. subtilis cells. Berberine working concentration was determined based on previous work (Avci et al., 2019). In our previous work, $75 \mu \mathrm{gmL}^{-1}$ berberine has been shown to only slightly affect $B$. subtilis 168 growth. Thus, $25 \mu \mathrm{gmL}^{-1}$ silibinin was combined with $75 \mu \mathrm{gmL}^{-1}$ berberine (Figure 3). Although either $25 \mu \mathrm{gmL}^{-1}$ silibinin or $75 \mu \mathrm{gmL}^{-1}$ berberine has no significant effect on cell growth alone, their combination killed the cells. Since plant-derived natural products are known to have multiple targets to cause death, EtBr accumulation test was further carried out to verify that silibinin's EPI property was responsible for the observed behavior.

Figure 3. Effect of the berberine and silibinin combination on microbial growth.

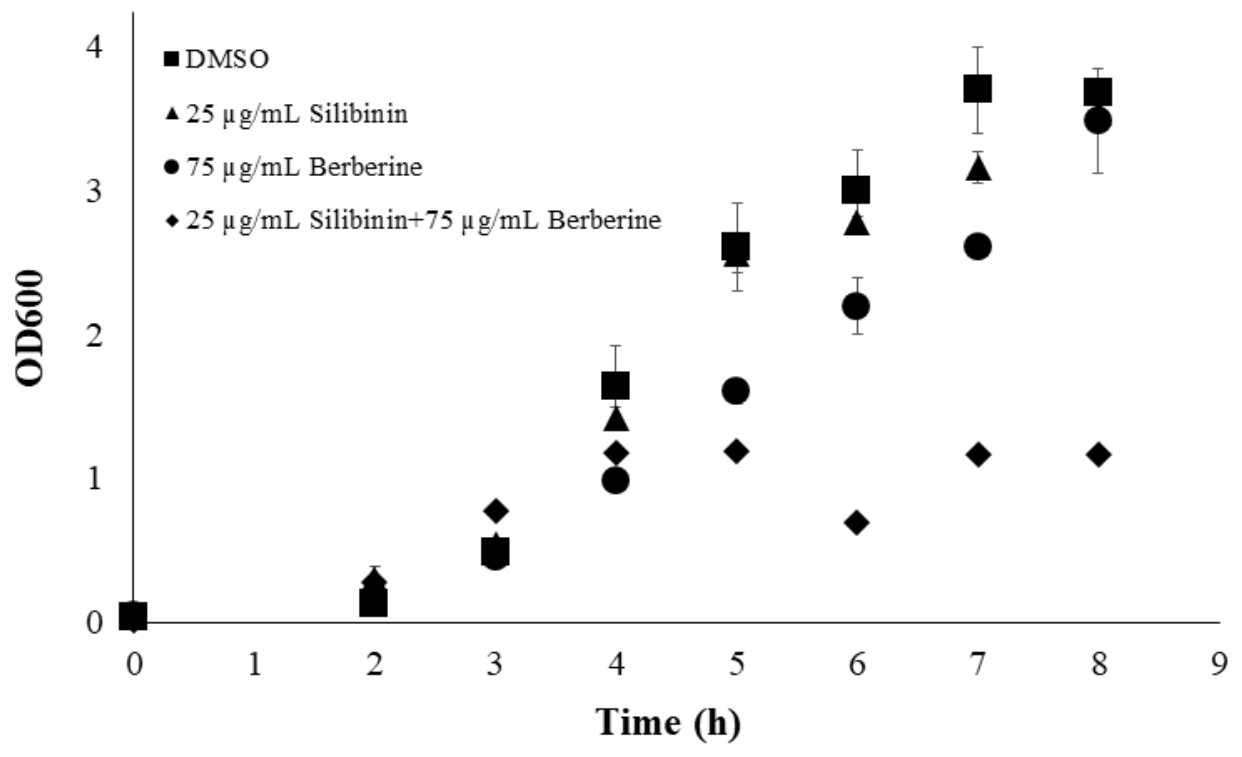

\subsection{Effect of Silibinin on Efflux Pumps of $B$. subtilis 168}

$\mathrm{EtBr}$ accumulation is a commonly used assay to monitor the activity of efflux pumps. EtBr passes the cell membrane and binds by intercalating between DNA base pairs. Therefore, its intracellular presence can be detected by fluorometry $(540 \mathrm{~nm}$ as excitation and $590 \mathrm{~nm}$ as emission) (Steinfels et al., 2004). However, free $\mathrm{EtBr}$ is also continuously effluxed through efflux pumps. Thus, in the presence of an EPI, the increase in fluorescence would be expected to be higher.

To this end, EtBr accumulation in B. subtilis 168 cells in the presence of silibinin was investigated to assess its EPI potential. The selected concentrations were believed to facilitate EtBr accumulation, while not causing cell death. Based on the growth results obtained in the presence of increasing concentrations of silibinin (Figure 2), this assay was carried out with 25 and $50 \mu \mathrm{gmL}^{-1}$ silibinin.

In the control cell sample, which was treated with DMSO (the solvent of silibinin), fluorescence intensity was pretty constant after approximately $50 \mathrm{~s}$. This showed that EtBr was inside the cells but with the action of the pumps, its concentration remained at its steady state value. The increase in fluorescence intensity due to $\mathrm{EtBr}$ accumulation was highest in the presence of $50 \mu \mathrm{gmL}^{-1}$ silibinin. Since this concentration had a considerable effect on cell growth (Figure 2), this observed behavior in fluorescence could as well be a result of released genetic material due to cell death. When silibinin concentration was dropped to $25 \mu \mathrm{gmL}^{-1}$, the 
recorded fluorescence was only slightly affected which demonstrated that silibinin displayed an EPI character (Figure 4).

Figure 4. EtBr accumulation in B. subtilis in the presence of silibinin.

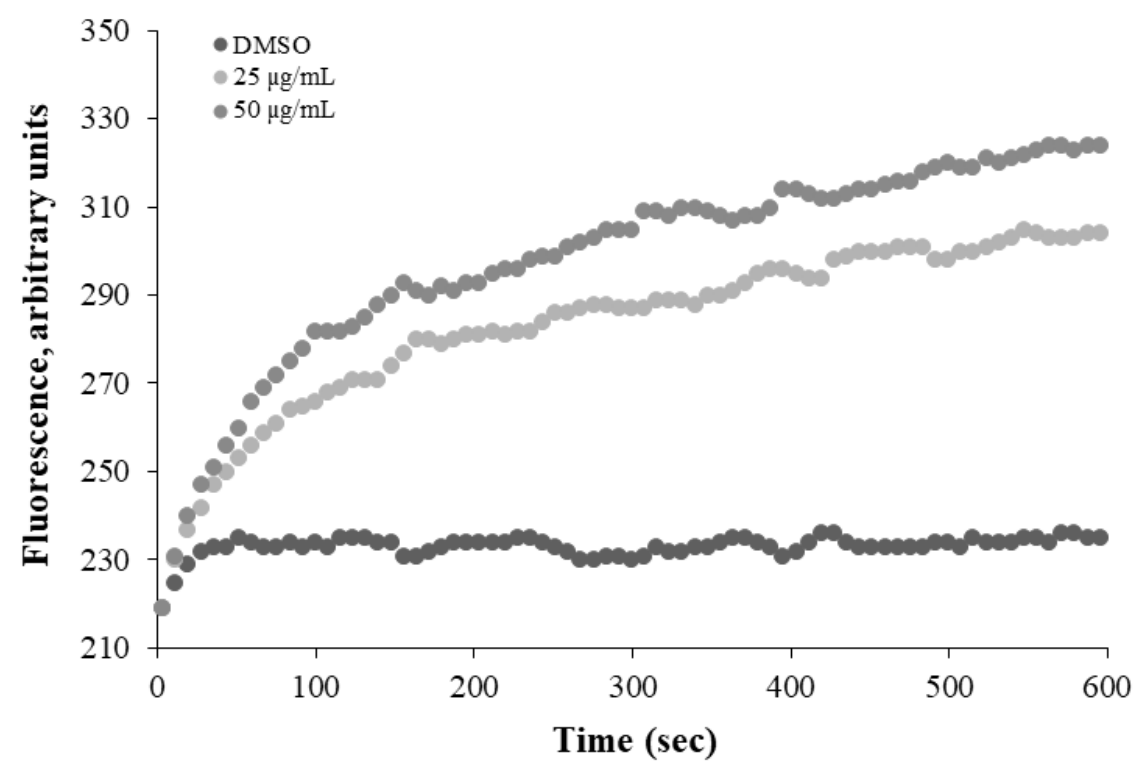

Due to the significant genomic abundance compared to other Gram-positives, B. subtilis transporters have been extensively studied (Lorca et al., 2007; Neyfakh et al., 1991). Blt and Bmr (Ahmed et al., 1995; Baranova et al., 1999; Woolridge et al., 1997) of MFS, YerP (Tsuge et al., 2001) of RND superfamily, EbrAB (Masaoka et al., 2000) of SMR family, and BmrA (Steinfels et al., 2004) of ABC superfamily are some of the well-characterized efflux pumps in B. subtilis. Among these pumps, EtBr has been reported to be a substrate for BmrA, Blt, Bmr, and EbrAB (Ahmed et al., 1995; Masaoka et al., 2000; Neyfakh et al., 1991; Steinfels et al., 2004). The results strongly suggest that the silibinin binds and inhibits the efflux pump(s) of $B$. subtilis 168 so that $\mathrm{EtBr}$ uptake rate is higher than its efflux rate in the presence of silibinin. This leads to continuous EtBr accumulation in the cells.

Silibinin has been reported to inhibit the efflux through the mammalian P-glycoprotein (Zhou et al., 2004) and since BmrA of B. subtilis cells is a homologue of P-glycoprotein (Steinfels et al., 2004), it could be proposed that the ABC transporter BmrA could be a target of silibinin. However, plant derived molecules are commonly known as multi-target molecules: thus, silibinin could be binding the other pumps in B. subtilis for which $\mathrm{EtBr}$ is a substrate.

\section{CONCLUSION}

Within the scope of this study, silibinin was assessed as a candidate for inhibiting efflux mechanisms in B. subtilis 168 cells. Here, it demonstrated a significant efflux pump inhibitor activity in the EtBr accumulation test and enhanced the activity of berberine. Because of the multi-target properties of the plant-derived molecules, it was not possible to determine the exact target of the silibinin. Further studies that will involve the purified efflux pump proteins are necessary. Although $B$. subtilis 168 is not a pathogenic microorganism, it is a well-known model organism for low $\mathrm{G}+\mathrm{C}$ Gram-positives including many pathogenic bacteria, which means that silibinin could have comparable effects on these pathogenic bacteria. For future work, the synergistic antimicrobial effect of silibinin with available drugs or antibiotics could be assessed to overcome the bacterial defense mechanisms. 


\section{Declaration of Conflicting Interests and Ethics}

The authors declare no conflict of interest. This research study complies with research and publishing ethics. The scientific and legal responsibility for manuscripts published in IJSM belongs to the authors.

\section{Authorship Contribution Statement}

Fatma Ece Altinisik Kaya: Design of the study, performing the experiments, writing. Basak Atas: Design of the study, performing the experiments, writing. Fatma Gizem Avci: Design of the study, writing, editing, validation. Fatma Ece Altinisik Kaya and Basak Atas contributed equally to this work.

\section{Orcid}

Fatma Ece Altinisik Kaya (iD https://orcid.org/0000-0002-5398-0220

Basak Atas (i) https://orcid.org/0000-0001-9959-6964

Fatma Gizem Avci (D) https://orcid.org/0000-0001-6618-0487

\section{REFERENCES}

Amsterdam, D. (1997). Susceptibility testing of antimicrobials in liquid media. In V. Loman (Ed.), Antibiotics in laboratory medicine (pp. 51-111). Maple Press.

Ahmed, M., Lyass, L., Markham, P. N., Taylor, S. S., Vazquez-Laslop, N., Neyfakh, A. A. (1995). Two highly similar multidrug transporters of Bacillus subtilis whose expression is differentially regulated. J. Bacteriol., 177(14), 3904-3910. https://doi.org/10.1128/jb.177.1 4.3904-3910.1995

Avci, F. G., Atas, B., Aksoy, C. S., Kurpejovic, E., Toplan, G. G., Gurer, C., Guillerminet, M., Orelle, C., Jault, J.M., Akbulut Sariyar, B. (2019). Repurposing bioactive aporphine alkaloids as efflux pump inhibitors. Fitoterapia, 139, 104371. https://doi.org/10.1016/j.fito te.2019.104371

Baranova, N. N., Danchin, A., Neyfakh, A. A. (1999). Mta, a global MerR-type regulator of the Bacillus subtilis multidrug-efflux transporters. Mol. Microbiol., 31(5), 1549-1559. https://doi.org/10.1046/j.1365-2958.1999.01301.X

Cai, J. Y., Wang, Y. Y., Ma, K., Hou, Y. N., Li, J., Yao, G. D., Liu, W. W., Otkur, W., Hayashi, T., Itoh, K., Tashiro, S. I., Ikejima, T. (2017). Silibinin protects Staphylococcus aureus from UVC-induced bactericide via enhanced generation of reactive oxygen species. R.S.C. Adv., 7(53), 33194-33200. https://doi.org/10.1039/c7ra03981f

Chan, B. C. L., Ip, M., Lau, C. B. S., Lui, S. L., Jolivalt, C., Ganem-Elbaz, C., Litaudon, M., Reiner, N. E., Gong, H., See, R. H., Fung, K. P., Leung, P. C. (2011). Synergistic effects of baicalein with ciprofloxacin against NorA over-expressed methicillin-resistant Staphylococcus aureus (MRSA) and inhibition of MRSA pyruvate kinase. $J$. Ethnopharmacol., 137(1), 767-773. https://doi.org/10.1016/j.jep.2011.06.039

de Oliveira, D. R., Tintino, S. R., Braga, M. F. B. M., Boligon, A. A., Athayde, M. L., Coutinho, H. D. M., de Menezes, I. R. A., Fachinetto, R. (2015). In vitro antimicrobial and modulatory activity of the natural products silymarin and silibinin. Bio.Med. Res. Int., 292797. https://doi.org/10.1155/2015/292797

Dobiasová, S., Řehořová, K., Kučerová, D., Biedermann, D., Káňová, K., Petrásková, L., Koucká, K., Václavíková, R., Valentová, K., Ruml, T., Macek, T., Křen, V., Viktorová, J. (2020). Multidrug resistance modulation activity of silybin derivatives and their antiinflammatory potential. Antioxidants, 9(5), 455. https://doi.org/10.3390/antiox9050455

Du, D., van Veen, H. W., Murakami, S., Pos, K. M., Luisi, B. F. (2015). Structure, mechanism and cooperation of bacterial multidrug transporters. Curr. Opin. Struct. Biol., 33, 76-91. https://doi.org/10.1016/j.sbi.2015.07.015 
Gibbons, S., Moser, E., Kaatz, G. W. (2004). Catechin gallates inhibit multidrug resistance (MDR) in Staphylococcus aureus. Planta Med., 70(12), 1240-1242. https://doi.org/10.1055 /s-2004-835860

Gibbons, S., Oluwatuyi, M., Kaatz, G. W. (2003). A novel inhibitor of multidrug efflux pumps in Staphylococcus aureus. J. Antimicrob. Chemother., 51, 13-17. https://doi.org/10.1093/ja $\mathrm{c} / \mathrm{dkg} 044$

Jin, G., Zhang, J., Guo, N., Feng, H., Li, L., Liang, J., Sun, K., Wu, X., Wang, X., Liu, M., Deng, X., Yu, L. (2011). The plant alkaloid piperine as a potential inhibitor of ethidium bromide efflux in Mycobacterium smegmatis. J. Med. Microbiol., 60(2), 223-229. https://doi.org/10.1099/jmm.0.025734-0

Kumar, A., Khan, I. A., Koul, S., Koul, J. L., Taneja, S. C., Ali, I., Ali, F., Sharma, S., Mirza, Z. M., Kumar, M., Sangwan, P. L., Gupta, P., Thota, N., Qazi, G. N. (2008). Novel structural analogues of piperine as inhibitors of the NorA efflux pump of Staphylococcus aureus. $J$. Antimicrob. Chemother., 61, 1270-1276. https://doi.org/10.1093/jac/dkn088

Lamut, A., Peterlin Mašič, L., Kikelj, D., Tomašič, T. (2019). Efflux pump inhibitors of clinically relevant multidrug resistant bacteria. Med. Res. Rev., 39(6), 2460-2504. https://doi.org/10.1002/med.21591

Lorca, G. L., Barabote, R. D., Zlotopolski, V., Tran, C., Winnen, B., Hvorup, R. N., Stonestrom, A. J., Nguyen, E., Huang, L. W., Kim, D. S., Saier, M. H. (2007). Transport capabilities of eleven gram-positive bacteria: Comparative genomic analyses. Biochimi. Biophys. Acta, 1768(6), 1342-1366. https://doi.org/10.1016/j.bbamem.2007.02.007

Magiorakos, A. P., Srinivasan, A., Carey, R. B., Carmeli, Y., Falagas, M. E., Giske, C. G., Harbarth, S., Hindler, J. F., Kahlmeter, G., Olsson-Liljequist, B., Paterson, D. L., Rice, L. B., Stelling, J., Struelens, M. J., Vatopoulos, A., Weber, J. T., Monnet, D. L. (2012). Multidrug-resistant, extensively drug-resistant and pandrug-resistant bacteria: An international expert proposal for interim standard definitions for acquired resistance. Clin. Microbiol. Infect., 18(3), 268-281. https://doi.org/10.1111/j.1469-0691.2011.03570.x

Mahmood, H. Y., Jamshidi, S., Sutton, J. M., Rahman, K. M. (2016). Current Advances in Developing Inhibitors of Bacterial Multidrug Efflux Pumps. Curr. Med. Chem., 23(10), 1062-1081. https://doi.org/10.2174/0929867323666160304150522

Masaoka, Y., Ueno, Y., Morita, Y., Kuroda, T. (2000). A Two-Component Multidrug Efflux Pump, EbrAB, in Bacillus subtilis. J. Bacteriol., 182(8), 2307-2312. https://doi.org/10.1128/JB.182.8.2307-2310.2000

Neyfakh, A. A., Bidnenko, V. E., Chen, L. B. (1991). Efflux-mediated multidrug resistance in Bacillus subtilis: similarities and dissimilarities with the mammalian system. Proc. Natl. Acad. Sci. U.S.A., 88(11), 4781-4785. https://doi.org/10.1073/pnas.88.11.4781

Schwarz, S., Chaslus-Dancla, E. (2001). Use of antimicrobials in veterinary medicine and mechanisms of resistance. Vet. Res., 32(3-4), 201-225. https://doi.org/10.1051/vetres:2001 $\underline{120}$

Serçinoğlu, O., Senturk, D., Altinisik Kaya, F. E., Avci, F. G., Frlan, R., Ozbek, P., Jault, J.M., Sariyar Akbulut, B. (2020). Identification of novel inhibitors of the ABC transporter BmrA. Bioorg. Chem., 105, 104452. https://doi.org/10.1016/j.bioorg.2020.104452

Shen, X., Liu, H., Li, G., Deng, X., Wang, J. (2018). Silibinin attenuates Streptococcus suis serotype 2 virulence by targeting suilysin. J. Appl. Microbiol., 126(2), 435-442. https://doi.org/10.1111/jam.14149

Steinfels, E., Orelle, C., Fantino, J.R., Dalmas, O., Rigaud, J. L., Denizot, F., Di Pietro, A., Jault, J. M. (2004). Characterization of YvcC (BmrA), a Multidrug ABC Transporter Constitutively Expressed in Bacillus subtilis. Biochemistry, 43(23), 7491-7502. https://doi.org/10.1021/bi0362018

Stermitz, F. R., Lorenz, P., Tawara, J. N., Zenewicz, L. A., Lewis, K. (2000). Synergy in a 
medicinal plant: Antimicrobial action of berberine potentiated by 5'-methoxyhydnocarpin, a multidrug pump inhibitor. Proc. Natl. Acad. Sci. U.S.A., 97(4), 1433-1437. https://doi.org/10.1073/pnas.030540597

Tsuge, K., Ohata, Y., Shoda, M. (2001). Gene yerP, involved in surfactin self-resistance in Bacillus subtilis. Antimicrob. Agents Chemother., 45(12), 3566-3573. https://doi.org/10.1128/AAC.45.12.3566-3573.2001

Van Duijkeren, E., Schink, A. K., Roberts, M. C., Wang, Y., Schwarz, S. (2018). Mechanisms of bacterial resistance to antimicrobial agents. In S. Schwarz, L. Cavaco, J. Shen (Ed.), Antimicrobial Resistance in Bacteria from Livestock and Companion Animals (pp. 51-82). Washington: ASM Press. https://doi.org/10.1128/microbiolspec.arba-0019-2017

Wang, D., Xie, K., Zou, D., Meng, M., Xie, M. (2018). Inhibitory effects of silybin on the efflux pump of methicillin-resistant Staphylococcus aureus. Mol. Med. Rep., 18(1), 827-833. https://doi.org/10.3892/mmr.2018.9021

Wlcek, K., Koller, F., Ferenci, P., Stieger, B. (2013). Hepatocellular organic anion-transporting polypeptides (OATPs) and multidrug resistance-associated protein 2 (MRP2) are inhibited by silibinin. Drug Metab. Dispos., 41(8), 1522-1528. https://doi.org/10.1124/dmd.113.051 $\underline{037}$

Woolridge, D. P., Vazquez-Laslop, N., Markham, P. N., Chevalier, M. S., Gerner, E. W., Neyfakh, A. A. (1997). Efflux of the Natural Polyamine Spermidine Facilitated by the Bacillus subtilis Multidrug Transporter Blt. J. Biol. Chem., 272(14), 8864-8866. https://doi.org/10.1074/jbc.272.14.8864

Zhou, S., Lim, L. Y., Chowbay, B. (2004). Herbal Modulation of P-Glycoprotein. Drug Metab. Rev., 36(1), 57-104. https://doi.org/10.1081/DMR-120028427 